\title{
LISE ÖĞRENCILERININ KÜRESEL İKLIM DEĞişiKLIĞi HAKKINDAKi GÖRÜŞLERi
}

Ali Derya Atika, ${ }^{\star}$, Yakup Doğan ${ }^{b}$

\section{ÖZET}

Bu çalışmanın amacı, lise öğrencilerin küresel iklim değişikliğinin sebepleri, etkileri ve iklim değişikliği ile mücadele ve halkın adaptasyonu konusundaki bilgi düzeylerini ve iklim değişikliği hakkındaki görüşlerini belirlemektir. İklim değişikliği yüzyılın en önemli küresel çevre problemlerinden biridir. Küresel iklim değişikliği önlenemezse gelecekte geri dönüşü mümkün olmayan sonuçlar doğuracaktır. Bu nedenle bireylerin bu konudaki bilgi ve farkındalık düzeylerinin belirlenmesi problemin çözümüne katkı sağlayacaktır. Araştırmada tarama modeli kullanıımıştır. Araştırmaya 9. ve 10. sınıftan 249 öğrenci katılmıştır. Bireylerden bilgi toplamak için kapalı uçlu ve açık uçlu sorular içeren "Küresel İklim Değişikliği Anketi” kullanılmıştır. Katıımcılara iklim değişikliğinin tanımı, sebepleri, etkileri, endişe düzeyleri ve iklim değişikliğini önleme ve mücadele soruları sorulmuştur. Elde edilen nicel verilerin analizinde basit betimsel istatistik (yüzde ve frekans) ve nitel verilerin analizinde betimsel analiz yöntemi kullanılmıştır. Katıııcıların, iklim değişikliğinin nedenleri, etkileri ve iklim değişikliğine karşı nasıl mücadele edileceği hakkında yeterli bilgiye sahip olmadıkları belirlenmiştir. Katılımcıların yarıya yakını küresel ikilim değişikliğini tanımlayamamış (bilgim yok şeklinde ifade etmişlerdir) ve tanımlar incelendiğinde tanımların genel olarak yüzeysel ve bilimsel olmadığı görülmüştür. Katılımcıların iklim değişikliği hakkında kavram yanılgıları olduğu belirlenmiştir. Katılımcılara göre, küresel iklim değişikliğinin en önemli sebepleri çevre kirliliği ve insanların bilinçsiz davranışlarıdır. Katılımcıların çok büyük bir kısmı küresel iklim değişikliğinin neden olabileceği olumsuzluklardan endişe duymaktadır. Genel olarak katıımcılar, küresel iklim değişiminin etkilerini artırmada atık uygulamalarının enerji ile ilgili uygulamalardan daha etkili olduğunu düşünmektedir. Sonuç olarak; öğrencilere iklim değişikliği ile mücadele edebilmek için bireylerin üzerine düşen görev ve sorumluluklar erken yaşlarda öğretilmelidir. Öğrencilere iklim değişikliği ile mücadele edilebileceği vurgulanmalıdır. İklim değişikliğinin etkilerini azaltmak için ülke genelinde geri dönüşüm uygulamaları arttııımalıdır.

Anahtar Kelimeler: Küresel İklim Değişikliği, Lise Öğrencileri, Çevre Sorunları

\section{MAKALE HAKKINDA}

GönderimTarihi: 24 Mayıs 2019

Revize Tarihi: 11 Haziran 2019

Kabul Tarihi: 14 Haziran 2018

DOI: 10.31805/acjes.569937

a, "** Sorumlu Yazar: Ali Derya Atik, Kilis 7 Aralık Üniversitesi, Eğitim Fakültesi, Kilis, Türkiye.

E-Mail: alideryaatik@gmail.com

Dhttps://orcid.org/0000-0002-5841-6004

'Kilis 7 Aralık Üniversitesi, Eğitim Fakültesi, Kilis, Türkiye.

E-Mail: yakupdogan@kilis.edu.tr

Dhttps://orcid.org/0000-0003-0721-1268

E-ISSN: 2602-3342

Copyright $\odot$ ACJES 


\title{
HIGH SCHOOL STUDENTS' VIEWS ON GLOBAL CLIMATE CHANGE
}

Ali Derya Atik ${ }^{a, *}$, Yakup Doğan

\begin{abstract}
The aim of the study is to determine the causes, effects and struggle to fight climate change and public adaptation and their views of high school students about climate change. Climate change is one of the most important global environmental problems of this century. If global climate change cannot be prevented it will cause irreparable damage in the future. So, determining the individual's information and awareness on this issue will contribute to the solution of the problem. Survey research was used in this study. 249 students from 9th and 10th grade participated. "Global Climate Change Questionnaire" which is included closed-ended and open-ended questions was used to collect data from individuals. The questions that are the definition of climate change, causes, effects, levels of concerns and awareness of activities about preventing and struggle to fight climate change were asked to participants. In the analysis of quantitative data, simple descriptive statistics (percentage and frequency) and the analysis of qualitative data were analyzed by using descriptive analysis method. It was determined that participants did not have enough information about the causes, effects and how to struggle against climate change. Approximately half of the participants were unable to define the global climate change (they stated that they did not have any information) and when the participants' definitions were analyzed it was seen that the definitions were superficial and non-scientific. It was determined that participants had misconceptions about climate change. According to the participants, the most important reasons for global climate change were environmental pollution and the unconscious behavior of people. Most participants are concerned about the negative consequences of global climate change. Generally, participants were thought that waste practices are more effective than energy-related practices in increasing the impacts of global climate change. As a result; in order to be able to combat climate change, the duties and responsibilities of individuals should be taught at an early age. It must teach students that climate change can be tackled be. To reduce the impacts of climate change, recycling practices should be increased across the country.
\end{abstract}

Keywords: Global Climate Change, High School Students, Environmental Problems

ARTICLE INFO
Recived: 24 May 2019
Revisedi: 11 June 2019
Accepted: 14 June 2018
DOI: 10.31805/acjes.569937
a,** Sorumlu Yazar: Ali Derya Atik, Kilis 7 Aralık University, Faculty of Education, Kilis, Turkey.
E-Mail: alideryaatik@gmail.com
(Dhttps://orcid.org/0000-0002-5841-6004
bKilis 7 Aralık University, Faculty of Education, Kilis, Turkey.
E-Mail: yakupdogan@kilis.edu.tr
Dhttps://orcid.org/0000-0003-0721-1268
E-ISSN: 2602-3342
Copyright @ ACJES


Nüfus artışına ve teknolojik gelişmelere bağlı olarak insanlar temel ihtiyaçlarını karşılamakla yetinmemiş, sınırsız isteklerini, sınırlı kaynakları kullanarak temin etmeye çalışmıştır. Bu süreçte doğal kaynakların kullanımı ve atık miktarındaki artış pek çok çevre sorununun ortaya çıkmasına neden olmuştur. Hızlı nüfus artışına bağlı olarak besin ihtiyacı artmış ve artan ihtiyaçları karşılamak için verimli tarım alanları kentleşme uğruna yok edilmiş ve kentlere göçle birlikte şehirlerde çarpık kentleşme sorunu doğal dengenin bozulma sürecini hızlandırmıştır (Akgün, Duruk ve Tokur, 2017).

Son yüz yılda insan nüfusuna bağlı olarak artan tüketimin, doğal çevreyi olumsuz yönde etkileyerek küresel iklim değişikliğini hızlandırdığı ifade edilmektedir (Swim, Clayton ve Howard, 2011). Küresel iklim değişikliği, bașta sanayide ve ulaşımda gerekli enerjinin fosil yakıtlardan karşılanması, ormanların yok edilmesi ve diğer pek çok insan faaliyetleri sonucu atmosferde doğal olarak bulunan metan $(\mathrm{CH} 4)$ ve karbon dioksit (CO2) gazlarının yanı sıra sentetik kimyasalların (kloroflorokarbon-CFC) artışına bağlı olarak oluşan sera etkisi ile dünyamızın ortalama sıcaklığın yükselmesi olarak tanımlanabilir (Aydın, 2014). Küresel iklim değişikliği, insanoğlunun etkisi ile ortaya çıkan, sonuçları ile tüm dünyayı etkileyen ve üzerinde çokça tartışılan en önemli çevre sorunlarından biridir (Demircan ve diğ., 2016). Özellikle son yıllarda dünyanın farklı coğrafyalarında yaşanan olağanüstü hava olayları, buzulların hızla erimesi, küresel iklim değişikliğinin etkilerini ve boyutunu hissettirmektedir. Devletler sera gazlarının salınımını azaltıcı birçok çalışmayı iş birliği yaparak yürütse de yine de yeterince başarılı oldukları söylenemez.

Çevrenin asli bir öğesi olan insan da her geçen gün artan çevre sorunlarından doğal olarak etkilenmektedir. Çevre sorunların temelinde, bireylerin çevre hakkında bilgilerinin, çevreye yönelik tutumlarının, değer ve farkındalıklarının düşük olması yer almaktadır. Çevre sorunlarının çoğu, bu konulara yeterince önem vermeyen kişilerin davranışlarından kaynaklanmaktadır. İnsan ve çevre arasındaki etkileşimin sağlıklı bir şekilde yürütülebilmesi için çevre bilincine sahip ve çevreye duyarlı bireylerin yetiştirilmesi gerekmektedir. Bu farkındalığa, bilince, tutuma ve duyarlı davranışlara sahip bireylerin yetiştirilmesi ancak etkili bir çevre eğitimi ile sağlanabilir (Akgün ve Atmaca, 2015; Akgün ve diğ., 2017; Aydın, 2014; Ergin, Akbay, Özdemir ve Uzun, 2017; Kışoğlu, Yıldırım, Salman ve Sülün, 2016). Artan çevre sorunları, çevre eğitiminin uygulanmasında birtakım sorunların olduğunu düşündürmektedir. Nitekim, literatürde farklı kademelerde öğrenim gören öğrencilerin çevre hakkında yeterli bilgiye sahip olmadıklarını (Akgün ve Atmaca, 2015; Akgün ve diğ., 2017; Bozdoğan, 2011; Bozkurt ve Kaya, 2008; Khalid, 2003; Topçu ve Atabey, 2016; Uğulu ve Erkol, 2013), çevre sorunlarına yeterince ilgi göstermediklerini, çevre ile ilgili faaliyetlere yeterince katılmadıklarını ve çevre sorunlarına karşı duyarlılıklarının az olduğunu ifade eden araştırmalar (Aksu, Temeloğlu, Özkaya ve Gündeğer, 2012; Oğuz, Çakıcı ve Kavas, 2011; Özdemir, 2010) bu düşünceyi destekler niteliktedir. Benzer şekilde yurt dışında ve ülkemizde farklı eğitim kademelerindeki öğrencilerin, öğretmen adaylarının ve öğretmenlerin genel olarak küresel iklim değişikliğinin nedenleri ve sonuçları hakkında sınırlı ön bilgilere ve pek çok kavram yanılgısına sahip oldukları görülmektedir (Aksan ve Çelikler, 2013; Arsal, 2010; Ayvacı ve Çoruhlu, 2009; Bahar ve Aydın, 2002; Bal, 2004; Bozdoğan, 2011; Bozdoğan ve Yanar, 2010; Bozkurt ve Aydoğdu, 2004; Bozkurt, Aydın, Yaman, Uşak ve Gezer, 2005; Darçın, Bozkurt, Hamalosmanoğlu ve Köse, 2006; Derman, Çakmak, Yaşar ve Gürbüz, 2013; Ergin ve diğ., 2017; Keinonen, Palmberg, Kukkonen, Panula ve Vilkonis, 2016; Khalid, 2003; Kılınç, Stanisstreet ve Boyes, 2008; Oluk ve Oluk, 2007; Papadimitriou, 2004; Pekel, Kaya ve Demir, 2007; Şenel ve Güngör, 2009; Ünlü, Sever ve Akpınar, 2011). Kavram yanılgısı, bireylerin yaşantı veya gözlemleri ile kazanmış oldukları bilgilere bilimsel olarak doğru olmayan, kendilerine özgü yorumlar ve anlamlar kazandırmaları olup, bu yanlış fikirler değiştirilmesi zor ve genellikle yeni bilginin yapısını bozar niteliktedir (Bahar, 2003). Öğrencilerin iklim değişikliği kavramını yanlış öğrenmeleri, bu konunun önemini anlamalarını engellediği gibi diğer konularla ilgili yanlış öğrenmelere de neden olabilir. Bu bakımdan kavram yanılgıIarının tespiti önemlidir. Bu çalışmada diğer çalışmalardan farklı olarak, iklim değişikliği konusunda ortaöğretim öğrencilerin bilgi düzeyleri, kavram yanılgıları, endişe düzeyleri ve iklim değişikliği ile mücadele ve halkın adaptasyonu konusunda farkındalıkları hakkında bilgi toplanmaya çalışıımış ve iklim değişikliği öğrenci gözünden pek çok yönü ile incelenmiştir. Literatürde iklim değişikliği ile mücadele ve halkın adaptasyonu konusunda öğrenci farkındalıklarını belirlendiği bir çalışmaya rastlanmamıştır. Ayrıca literatürde küresel iklim değişikliği ile ilgili çalışmaların yükseköğrenimde daha fazla olduğu ve lise düzeyinde fazla çalışma yapılamadığı tespit edilmiştir. 
Küresel iklim değişikliği gibi çevre sorunlarının çözümünde, çevreye karşı duyarlı, bilinçli ve sorunların çözümüne aktif katılan bireylerin yetiştirilmesi ile mümkün olabilecek bilinçli toplum oluşturulması çok önemlidir. Toplumsal farkındalığın arttırılması için eğitim kurumlarına, sivil toplum kuruluşlarına ve medyaya önemli görevler düșmektedir. Ayrıca iklim değişikliğinin etkilerini azaltmaya yönelik kamu kurum ve kuruluşları tarafından yürütülen faaliyetlerin görünürlüğü ve bireylerin konu hakkında farkındalıkları da iklim değişikliği ile mücadelede etkili olan bir diğer faktördür. İklim değişikliği konusu ilkokuldan yükseköğrenime kadar farklı eğitim kademelerinde ve fen bilimleri, biyoloji, coğrafya gibi farklı derslerde anlatılmaktadır. Lise düzeyindeki öğrencilerin iklim değişikliği ile ilgili ilk ve ortaokul yıllarından gelen kavram yanılgıları bu öğretim kademesinde düzeltilemeyecek olursa ileriki yıllarda da devam edecektir. Ortaöğretim düzeyinde öğrencilerinin kavram yanılgılarının ve bilgi düzeylerinin tespiti ile gerek ilk ve ortaokul öğretim programlarında bu konu ile ilgili eksikliklerin tespiti ve gerekli düzeltmelerin yapılması gerekse lise ve yükseköğrenime yönelik araştırma ve iyileştirme çalışmalarına yardımcı olacağı düşünülmektedir.

İklim değişikliğinin sebepleri, olası etkileri, yürütülen faaliyetler ve bireysel olarak üzerimize düşen görev ve sorumluluklar hakkında doğru bilgiye sahip bireyler yetiştirilmeden iklim değişikliği ile mücadele edilemeyeceğinden yola çıkarak, bu çalışmanın amacı katıımcıların konu hakkında bilgi düzeyleri, sahip oldukları eksik ve yanlış öğrenmeleri belirlemeye çalışmaktır. Ayrıca katılımcıların küresel iklim değişikliği hakkındaki endişe düzeyleri, günlük yaşamlarında sıklıkla karşılaşabilecekleri bazı uygulamaların iklim değiş̧ikliği üzerine etkisi hakkındaki görüşleri, iklim değişikliği ile ilgili mücadele ve halkın adaptasyonu konusunda yürütülen faaliyetler hakkındaki farkındalıkları belirlenmeye çalışıımıştır. Çalışmanın amacına uygun olarak aşağıdaki sorulara yanıtlar aranmıştır;

1. Küresel iklim değișikliğinin sebepleri, etkileri ve iklim değișikliği ile mücadele hakkında öğrencilerin bilgi düzeyleri nedir?

\section{Küresel iklim değişikliğine ilişkin öğrenci görüșleri nedir?}

3. Küresel iklim değişikliği hakkında öğrencilerin endişe düzeyleri nasıldır?

4. Küresel iklim değişikliğinin etkilerini azaltmaya yönelik uygulamalar hakkında öğrencilerin farkındalıkları nasıldır?

5. Küresel iklim değişikliği ile mücadele ve halkın adaptasyonu hakkında öğrencilerin farkındalıkları nasıldır?

\section{Yöntem}

\section{Araştırmanın Modeli}

Araştırmada betimsel araştırma yöntemlerinden tarama modeli kullanılmıştır. Araştırmaya konu olan belirli bir gruba ait bireylerin özelliklerini veya herhangi bir konuya ait yönelimlerini (yetenekleri, tutumları, fikirleri, inançları ve/veya bilgileri) tanımlamak amacıyla verilerin toplanması esasına dayanan araştırma türüne tarama araştırması (survey) denilmektedir (Fraenkel ve Wallen, 2009). Tarama araştırmalarda, araştırmaya konu olan olay, birey ya da nesne kendi koşulları içinde ve var olduğu gibi tanımlanmaya, veriler özetlenmeye ve niteliklerine göre gruplandııımaya çalışılır (Karasar, 2012).

\section{Örneklem}

Araştırmanın evrenini Ankara'nın Keçiören ilçesindeki Anadolu liselerinin 9. ve 10. sınıflarında öğrenim gören öğrenciler oluşturmaktadır. On birinci sınıftan itibaren alan seçimine bağlı olarak farklı dersler seçebilen lise öğrencileri, 9. ve 10. sınıfta ortak dersler görmektedir. Daha üst sınıflarda ve yükseköğrenim kurumlarında seçtikleri alana göre iklim değişikliği hakkında bilgi düzeyleri birbirinden farklı olabilir. Keçiören ilçesinde toplam 15 Anadolu Lisesi bulunmakta olup tüm sınıf seviyelerinde yaklaşık öğrenci sayısı 12000'dir (URL-1). Toplam öğrenci sayısının yarısını 9 ve 10. sınıflarda öğrenim gören öğrenciler oluşturduğu varsayılırsa, evrenin yaklaşık büyüklüğü 6000 öğrenci olacaktır. Seçkisiz örnekleme yöntemine göre \%90 güven aralığında ve hata payı \%5 kabul edildiğinde örneklem sayısı 259 olarak hesaplanmıştır. Ancak çalışma 2017-2018 Öğretim yılı ikinci dönemi sonuna geldiğinden ve bazı katılımcıların verileri eksik olduğundan 249 öğrenciden elde edilen veriler analiz edilebilmiştir. 


\section{Veri Toplama Aracı}

Araştırmada veri toplama aracı olarak araştırıcılar tarafından geliştirilen "Küresel İklim Değişikliği Anketi” kullanılmıştır. Anket hazırlanırken öncelikle küresel iklim değişikliği ile ilgili ortaöğretim öğrencilerinin bilmesi gereken konular (küresel iklim değişikliği sebepleri ve olası sonuçları, küresel iklim değişikliğinin günlük hayat üzerine olası etkileri) tespit edilmiş ve anketin kapsam sınırları tespit edilmiştir. Kapsam belirlendikten sonra bazı soruların açık uçlu (4 adet), bazı soruların öğrencilerin ifadelere katılma düzeyini belirleyebilmek için seçenekli olacak şekilde kapalı uçlu (4 adet) olarak hazırlanmasına karar verilmiştir. Anket ön çalışmasından sonra kapsam ve şekil geçerliği için iki alan uzmanı, bir biyoloji öğretmeni ve dil geçerliği için bir edebiyat öğretmeninin görüşlerine sunulmuştur. Pilot çalışmada ortaöğretim dokuzuncu sınıfta öğrenim gören 10 öğrenciden (örneklem dışında) anketi şekil, anlaşılabilirlik, ifadelerin açık/netliği gibi yönlerden değerlendirmeleri istenmiştir. Şekil yönünden işaretlemeleri kolaylıkla yapabilmeleri için renklendirme, adaptasyon sözcüğünün açıklaması olarak uyum sözcüğünün yazılması gibi düzeltme işlemlerinden sonra anket kullanıma hazır hale gelmiştir. Ankette küresel iklim değişikliğinin sebepleri, etkileri ve önlenmesine yönelik ifadelere katılma düzeyini belirtebilecekleri (çok iyi derecede bilgim var/ iyi derecede bilgim var/ az derecede bilgim var/ bilgim yok) sorular sorulmuştur. Katılımcıların seçenekleri işaretleyebilecekleri sorularda kendilerini olduğundan daha farklı gösterme eğiliminde olabilecekleri düşünüldüğünden, seçenekli soruların altında öğrencilerden "Küresel iklim değişikliği nedir?", "Küresel iklim değişikliğinin sebepleri nelerdir?" ve "Küresel iklim değişikliğinin olası etkileri nelerdir?" şeklinde açı uçlu soruları yanıtlamaları istenmiştir. Ankette öğrencilerin küresel iklim değişikliği hakkında endişe düzeylerini belirlemeye yönelik (çok endişe verici/ endişe verici/ endişe verici değil/ hiç endişe verici değil) ifadelerin yer aldığı bir soruya yer verilmiştir. Ortaöğretim öğrencilerin günlük yaşamda karşılaşabilecekleri iklim değişikliğini etkileyen 15 örnek olay, literatürde iklim değişikliği ile yürütülen çalışmalardan ve ders kitaplarından yararlanılarak belirlenmiştir. Örnek olayların karşısında öğrencilerin katııma düzeylerini (çok etkili/ etkili/ etkili değil/ hiç etkili değil) belirtebilecekleri ifadeler bulunmaktadır. Ayrıca iklim değişikliği ile mücadele ve halkın adaptasyonunda kamu kurum ve kuruluşlarının (devlet kurumları, belediyeler vs.) yürüttüğü çalışmalardan haberdar olup/olmadıkları ve haberdar iseler çalışma hakkında bildiklerini yazmaları istenmiştir. Öğrencilerin anketleri sınıf ayrımı gözetmeksizin öğrenci 1, 2, 3... şeklinde kodlanmıştır.

\section{Verilerin Analizi}

Verilerin analizinde kapalı uçlu sorulardan elde edilen nicel veriler için basit betimsel istatistik (yüzde ve frekans) ve açık uçlu sorulardan elde edilen nitel veriler için betimsel analiz yaklaşımı kullanılmıştır. Araştırmada toplanan veriler daha önceden belirlenen ve araştırma sorularının ortaya koyduğu temalara göre özetlenmiş ve yorumlanmaya çalışılmıştır. Bu amaçla elde edilen veriler, önce sistematik ve açık bir şekilde betimlenmiş, daha sonra yorumlanarak bir takım sonuçlara ulaşılmaya çalışılmıştır (Yıldırım ve Şimşek, 2011). Bu süreçte izlenen yol şu şekildedir: (a) Çerçevenin oluşturulması: Küresel iklim değişikliği ile ilgili ortaöğretim öğrencilerinin bilmesi gereken konular (küresel iklim değişikliği sebepleri, olası sonuçları ve küresel iklim değişikliğinin günlük hayat üzerine olası etkileri) araştırmanın kavramsal çerçevesini oluşturmaktadır. Kavramsal çerçeveye uygun olarak araştırma soruları hazırlanmış ve veri analizi için bir çerçeve oluşturulmuştur. Bu çerçeveye göre verilerin küresel iklim değişikliğinin tanımı, sebepleri ve etkileri olmak üzere üç tema altında düzenlenmesinin uygun olacağı düşünülmüştür. (b) Verilerin işlenmesi: Katılımcıların iklim değişikliği ile ilgili açık uçlu sorulara verdikleri yanıtlar, mümkün olduğu kadar özgün (orijinal) formuna sadık kalınarak önceden belirlenen temalar altında toplanmıştır. Ayrıca katılımcıların yazdıklarından doğrudan alıntılar yapılarak her bir tema altında örnek ifadeler de sunulmuştur. Veriler iki alan uzmanı tarafından eş zamanlı olarak incelenmiş ve tam bir fikir birliğine varılmadan diğer verinin analizine geçilmemiştir. (c) Bulguların tanımlanması: Düzenlenen veriler tanımlanmış ve örnek oluşturabilecek bazı öğrenci görüşleri doğrudan alıntılarla desteklenmiştir. Verilerin kolay anlaşılabilir ve okunabilir bir dille tanımlanmasına ve gereksiz tekrarlar yapılmamasına dikkat edilmiştir. Verilerin daha kolay anlaşılabilir olması için veri seti tablolar halinde sunulmuştur. Tablolar halinde sunulan verilerde sözcük sıklıkları hesaplanarak yorumlanma sürecine katkı sağlaması ve daha adil bir şekilde yorumlanması amaçlanmıştır. (d) Bulguların yorumlanması: Son olarak bulgular arasında ilişkilerin açıklanmasına ve yorumlanmasına çalışılmıştır.

\section{Bulgular}

Küresel iklim değişikliğinin sebepleri, etkileri ve iklim değişikliği ile mücadele konusunda öğrencilerin bilgi düzeylerine ilişkin bulgular aşağıda Grafik 1, 2 ve 3'de sunulmuştur. 


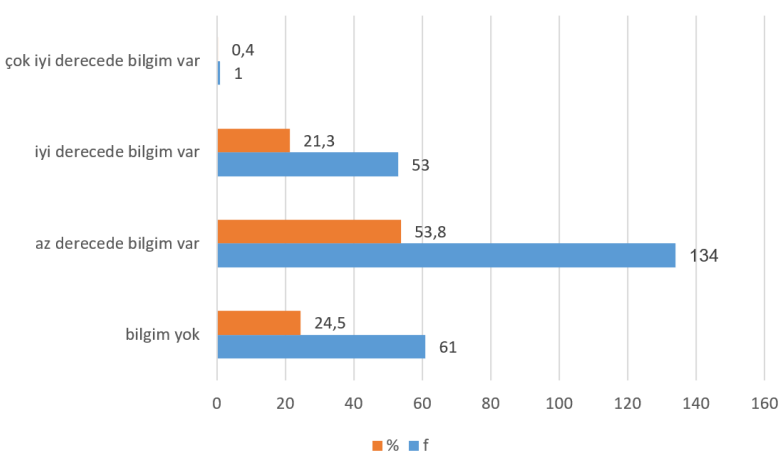

Grafik 1. Küresel iklim değişikliğinin sebepleri hakkında öğrencilerin bilgi düzeyleri

Küresel iklim değişikliğinin sebepleri hakkında bilgi sahibi olmayan öğrenciler \%24,5, az derecede bilgi sahibi olanlar \%53,8, iyi derecede bilgi sahibi olanlar \%21,3 ve çok iyi derecede bilgi sahibi olanlar sadece \%0,4'dür. Öğrencilerin küresel iklim değişikliğinin sebepleri hakkında yeterli bilgiye sahip olmadıkları ve bilgi düzeylerinin düşük olduğu tespit edilmiştir (Grafik 1).

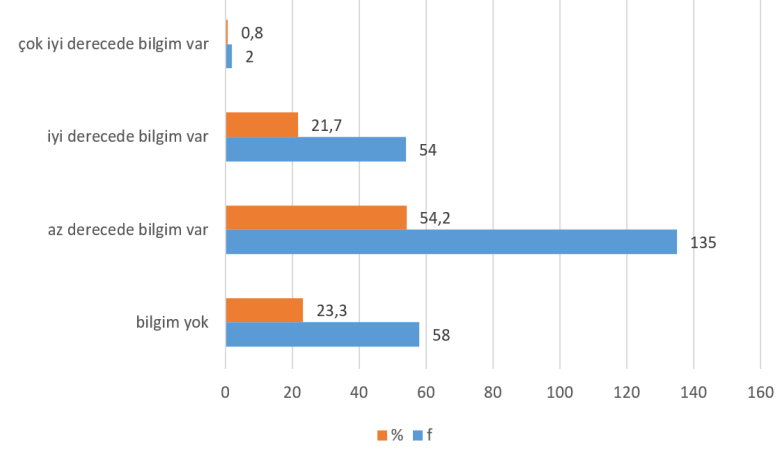

Grafik 2. Küresel iklim değişikliğinin etkileri hakkında öğrencilerin bilgi düzeyleri

Küresel iklim değişikliğinin etkileri hakkında bilgi sahibi olmayan öğrenciler \%23,3, az derecede bilgi sahibi olanlar \%54,2, iyi derecede bilgi sahibi olanlar \%21,7 ve çok iyi derecede bilgi sahibi olanlar \%0,8'dir. Öğrencilerin küresel iklim değişikliğinin etkileri hakkında yeterli bilgiye sahip olmadıkları ve bilgi düzeylerinin düşük olduğu belirlenmiştir (Grafik 2).

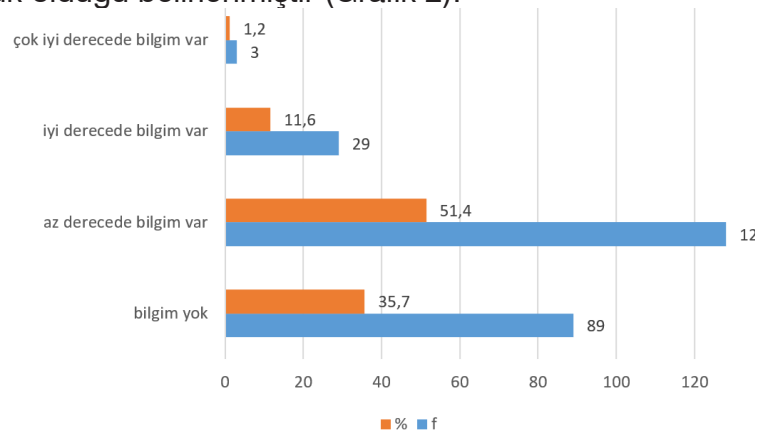

Grafik 3. Küresel iklim değişikliği ile ilgili mücadele hakkında öğrencilerin bilgi düzeyleri

Küresel iklim değişikliği ile mücadele hakkında bilgi sahibi olmayan öğrenciler \%35,7, az derecede bilgi sahibi olanlar $\% 51,4$, iyi derecede bilgi sahibi olanlar $\% 11,6$ ve çok iyi derecede bilgi sahibi olanlara sadece \%1,2'dir. Öğrencilerin küresel iklim değişikliği ile mücadele hakkında yeterli bilgiye sahip olmadıkları ve bilgi düzeylerinin düşük olduğu tespit edilmiştir (Grafik 3).

Küresel iklim değişikliğinin tanımı, sebepleri ve etkileri hakkında öğrenci görüşlerine ilişkin bulgular aşağıda Tablo 1, 2 ve 3’te sunulmuştur. 
Tablo 1. Küresel İklim Değişikliğinin Tanımına Ilişkin Öğrenci Görüşleri

\begin{tabular}{|c|c|c|c|c|}
\hline \multirow{2}{*}{ Tema } & \multirow{2}{*}{ Öğrenci Görüşleri (Kodlar) } & \multicolumn{2}{|c|}{ Sinıf } & \multirow{2}{*}{ Toplam } \\
\hline & & $9(\mathrm{f})$ & $10(f)$ & \\
\hline \multirow{11}{*}{$\begin{array}{l}\text { Küresel İklim } \\
\text { Değişikliğinin } \\
\text { Tanımı }\end{array}$} & Bilgim yok & 53 & 54 & 107 \\
\hline & İklimin değişerek çok sıcak veya çok soğuk olması & 20 & 19 & 39 \\
\hline & Havaların ısınması & 28 & 4 & 32 \\
\hline & Kutuplardaki buzulların erimesi & 18 & 6 & 24 \\
\hline & $\begin{array}{l}\text { İklimlerin zamanla yer değiştirmesi (hava olaylarının zamanında } \\
\text { gerçekleşmemesi) }\end{array}$ & 7 & 16 & 23 \\
\hline & Çevrenin bozulması ve oluşan dengesizlik & 6 & 6 & 12 \\
\hline & Ozon tabakasının delinmesi sonucu iklimlerde oluşan değişiklikler & 2 & 10 & 12 \\
\hline & Sera etkisi yaratan gazların atmosferde birikmesi & 0 & 12 & 12 \\
\hline & Güneş ışınlarının zararlarının artması & 2 & 1 & 3 \\
\hline & Atmosferi etkileyecek gazların çoğalması ile iklimin değişmesi & 2 & 0 & 2 \\
\hline & Dünyanın güneşe yaklaşması ile hava tabakasının delinmesi & 0 & 2 & 2 \\
\hline
\end{tabular}

Öğrencilerin yarıya yakını (107 kişi) küresel iklim değişikliğinin tanımını yapamamış ve bu konuda bilgi sahibi olmadığını ifade etmiştir. Tanımlar incelendiğinde ise 39 tanımın iklimin değişerek çok sıcak veya çok soğuk olması olduğu, "iklim değişikliği" ifadesinden yola çıkarak basit ve oldukça yüzeysel tanımladıkları belirlenmiştir. Tanımlardan 32'si havaların ısınması, 24'ü kutuplardaki buzulların erimesi, 23'ü iklimlerin yer değiştirmesi, 12'si çevrenin bozulması, 12'si ozon tabakasının delinmesi sonucu iklimlerin değişmesi, 12'si sera etkisi yaratan gazların atmosferde birikmesi, üçü güneş ışınlarının zararlarının artması, ikisi atmosferi etkileyecek gazların çoğalması ile iklimin değişmesi ve ikisi Dünya'nın güneşe yaklaşması ile hava tabakasının delinmesi şeklindedir (Tablo 1). İfadeler incelendiğinde, öğrencilerin büyük bir kısmının küresel iklim değişikliğini doğru tanımlayamadığı, bazı tanımlarda kavram yanılgılarının ve bilgi hatalarının olduğu görülmektedir. Aşağıda küresel iklim değişikliğine iliş̧kin örnek bazı öğrenci ifadelerine yer verilmiştir:

Öğrenci 21: "Küresel ısınma fosil yakıtlardaki zararlı gazların atmosferdeki ozon tabakasını delmesi sonucu güneş ışınlarının daha zarar verici hale gelmesidir".

Öğrenci 45: "Ozon tabakasının delinmesi sonucu gereğinden fazla güneş ışığının içeri alınması ve bu ışınların geri çıkamaması sonucu mevsimlerin ortalamalarından farklı yaşanmasıdır”.

Öğrenci 36: "Ortamdaki CO2 miktarının artması veya fabrika bacalarından çıkan zehirli gazların ozon tabakasını delmesi olayıdır".

Aşağıdaki Tablo 2'de görüldüğü gibi öğrencilerin yaklaşık üçte birlik bir bölümü $(n=70)$ küresel iklim değişikliğinin sebepleri konusunda bilgi sahibi olmadığını ifade etmiştir. Katılımcıların küresel iklim değişikliğinin sebeplerine yönelik ifadeleri incelendiğinde; 115'inin çevre kirliliği (fabrikalar, araba egzozları, piller, plastik poşet vb.), 55'inin insanların bilinçsiz davranmaları (bilinçsiz tüketim, geri dönüşüm yapmamak) olduğu görülmektedir. Benzer şekilde iklim değişikliğinin sebeplerinin insan kaynaklı olduğu diğer ifadeler fazla yakıt ve enerji tüketimi, ağaçlık alanların az olması ve nüfus artışıdır. İklim değişikliğinin sebepleri arasında ozon tabakasının delinmesi, dünyanın hareketi, coğrafi konum, dünyadaki azot miktarının azalması şeklinde ifadelerinde olduğu belirlenmiştir. Küresel iklim değişikliğinin sebepleri arasında bir ifade ise kıyametin yaklaşması şeklindedir. Sınırlı sayıda ifadeler arasında küresel ısınma (38) ve sera etkisi (3) yer almaktadır. Buzulların erimesi (5) ifadesi ise sebepten çok küresel iklim değişikliğinin sonucuna yönelik bir ifadedir. Aşağıda küresel iklim değişikliğinin sebeplerine ilişkin olarak örnek bazı öğrenci ifadelerine yer verilmiştir:

Öğrenci 15: "Güneşten dünyaya gelen fazla ısı ozon tabakasından çıkamaz ve burada kalır ve hava Isınır".

Öğrenci 197: “Gezegenimizin güneşe yaklaşması ve zararlı gazların ozon tabakasına zarar vermesi".

Öğrenci 201: "Çok miktarda parfüm, deodorant gibi ozon tabakalarına zarar verici maddelerin kullanılması ve egzoz dumanının artması". 
Tablo 2. Küresel Iklim Değişikliğinin Sebeplerine Illişkin Öğrenci Görüşleri

\begin{tabular}{|c|c|c|c|c|}
\hline \multirow{2}{*}{ Tema } & \multirow{2}{*}{ Öğrenci Görüşleri (Kodlar) } & \multicolumn{2}{|c|}{ Sinıf } & \multirow{2}{*}{ Toplam } \\
\hline & & $9(\mathrm{f})$ & $10(\mathrm{f})$ & \\
\hline \multirow{16}{*}{$\begin{array}{l}\text { Küresel İklim } \\
\text { Değişikliğinin } \\
\text { Etkileri }\end{array}$} & $\begin{array}{c}\text { Çevre kirliliği (fabrikalar, araba egzozları, piller, plastik poşet, fosil } \\
\text { yakıtlar bağlı gazlar, radyasyon) }\end{array}$ & 50 & 65 & 115 \\
\hline & Bilgim yok & 42 & 28 & 70 \\
\hline & $\begin{array}{l}\text { İnsanların bilinçsiz davranmaları (bilinçsiz tüketim, geri dönüşüm } \\
\text { yapmamak) }\end{array}$ & 18 & 37 & 55 \\
\hline & Küresel ısınma & 10 & 28 & 38 \\
\hline & Fazla yakıt ve enerji tüketimi & 16 & 4 & 20 \\
\hline & Ağaçlık alanların az olması & 6 & 7 & 13 \\
\hline & Ozon tabakasının delinmesi (zarar görmesi) & 3 & 9 & 12 \\
\hline & Buzulların erimesi & 3 & 2 & 5 \\
\hline & Dünyanın hareketi (Güneş etrafında dönmesi) & 4 & 0 & 4 \\
\hline & Zararlı güneş ışınları & 3 & 0 & 3 \\
\hline & Sera etkisi & 1 & 2 & 3 \\
\hline & Coğrafi konum & 1 & 0 & 1 \\
\hline & Kıyamet yaklaşması & 1 & 0 & 1 \\
\hline & Dünyadaki azot miktarının azalması & 0 & 1 & 1 \\
\hline & Biyosferin dengesinin bozulması & 0 & 1 & 1 \\
\hline & Nüfus artışı & 0 & 1 & 1 \\
\hline
\end{tabular}

Tablo 3. Küresel İklim Değişikliğinin Etkilerine İlişkin Öğrenci Görüşleri

\begin{tabular}{|c|c|c|c|c|}
\hline \multirow{2}{*}{ Tema } & \multirow{2}{*}{ Öğrenci Görüşleri (Kodlar) } & \multicolumn{2}{|c|}{ Sinıf } & \multirow{2}{*}{ Toplam } \\
\hline & & $9(\mathrm{f})$ & $10(f)$ & \\
\hline \multirow{23}{*}{$\begin{array}{l}\text { Küresel İklim } \\
\text { Değişikliğinin } \\
\text { Etkileri }\end{array}$} & Bilgim yok & 54 & 41 & 95 \\
\hline & Mevsimlerin düzensizliği (aşırı sıcak veya aşırı soğuk) & 21 & 23 & 44 \\
\hline & Buzulların erimesi & 20 & 19 & 39 \\
\hline & Hayvanların neslinin tükenmesi & 14 & 23 & 37 \\
\hline & Doğa (tüm canlılar) olumsuz etkilenir & 12 & 10 & 22 \\
\hline & Havaların ısınması & 7 & 8 & 15 \\
\hline & Ozon tabakasının delinmesi & 7 & 8 & 15 \\
\hline & Kuraklığa (çölleşme) neden olması & 7 & 7 & 14 \\
\hline & Hastalıklara yol açar & 6 & 7 & 13 \\
\hline & Deniz seviyesinin yükselmesi & 2 & 8 & 10 \\
\hline & Dünya yaşanmaz bir yer olur & 3 & 7 & 10 \\
\hline & İnsan yaşam kalitesini düşürür & 4 & 3 & 7 \\
\hline & Hayvanlar göç eder & 3 & 4 & 7 \\
\hline & Besin zinciri bozulur & 1 & 6 & 7 \\
\hline & Ormanların ve çevrenin yok olması & 1 & 1 & 2 \\
\hline & Ekonomik faaliyetler olumsuz etkilenir & 2 & 0 & 2 \\
\hline & Tarımsal ürünlerin verimi azalır & 0 & 2 & 2 \\
\hline & Yeryüzüne ulaşan UV ışınları artar & 0 & 2 & 2 \\
\hline & Ülkenin düzeni bozulur & 1 & 0 & 1 \\
\hline & Denizin tuzluluk oranı artar & 1 & 0 & 1 \\
\hline & Doğa olayları artar & 0 & 1 & 1 \\
\hline & Asit yağmurları artar & 0 & 1 & 1 \\
\hline & Canlıların genlerinde değișmeler olur & 0 & 1 & 1 \\
\hline
\end{tabular}


Küresel iklim değişikliğinin etkileri hakkında öğrenci görüşleri incelendiğinde katılımcıların yaklaşık üçte birlik kısmı ( $n=95$ ) bu konu hakkında da bilgi sahibi olmadığını ifade etmiștir. Katıımcıların ifadelerinde küresel iklim değişikliğinin etkileri; mevsim düzensizliği (44), buzulların erimesi (39), hayvanların neslinin tükenmesi (37), doğa (tüm canlılar) olumsuz etkilenmesi (22), havaların ısınması (15), kuraklığa (çölleşme) neden olması (14), hastalıklara yol açar (13), deniz seviyesinin yükselmesi (10), dünya yaşanmaz bir yer olur (10), insan yaşam kalitesini düşürür (7), hayvanlar göç eder (7), besin zinciri bozulur (7) şeklinde ifade edilmiştir. Önceki sorularda olduğu gibi, bu soruya verilen yanıtlarda da mevsimlerin aşırı sıcak veya aşırı soğuk geçeceği, diğer bir ifade ile mevsimlerde yaşanacak düzensizlikler en fazla tekrar eden ifade olmuştur. Diğer bir önemli ifade ise buzulların erimesidir. Ozon tabakasının delinmesi (15) ve yeryüzüne ulaşan uv ışınlarının artması (2) ifadeleri küresel iklim değişikliği hakkında edinilen yanlış bilgi veya kavram yanılgılarının bir diğer göstergesidir. Aşağıda küresel iklim değişikliğinin etkilerine ilişkin örnek bazı öğrenci ifadelerine yer verilmiştir:

Öğrenci 247: Küresel ısınma Dünya'nın en büyük çevre sorunudur. Sonunda hava sıcaklığı artış göstermektedir. Hava sıcaklığı arttıkça insanlar serinlemek için klima kullanmaya başlamaktadır ve bu da daha fazla küresel ısınmanın artmasını sağlamaktadır. Aynı zamanda küresel ısınma artıkça kutuplardaki buzullar erimeye başlamaktadır. Buzullar eridikçe Dünya'nın su oranı artış gösterir ve bu yüzden sellerin oluşma olasılığı artar.

Öğrenci 11: İklim düzeninin bozulması sonucunda bitki, hayvan ve toprak veriminde düşüş olur ve doğal kaynaklar tükenir. Doğal yaşam alanları değişen hayvanlar bulundukları ortamlara adapte olamazlar ve sonucunda nesilleri tükenir.

Öğrenci 90: Endemik türlerin varlığı tehlikeye düşeceğinden Dünya üzerindeki çeşitlilik azalır.

Öğrenci 108: Buzulların şiddetli erimesi, dolayısıyla denizlerde yükselme ve bazı karaların su altında kalması, ekstrem sıcaklıkların yaşanması ve tipik mevsim şartlarının dışında hava koşulları ile karşılaşmamız.

Öğrenci 131: Ozon tabakasının delinmesi, atmosfere kötü ve zararlı gazların yayılması, güneş ışınlarının süzülmeden dünyaya geçmesi ve ışınların çok zararlı hale gelmesi.

Küresel iklim değişikliği sorunu hakkında öğrencilerin endişe düzeyleri aşağıda Grafik 4'de sunulmuştur.

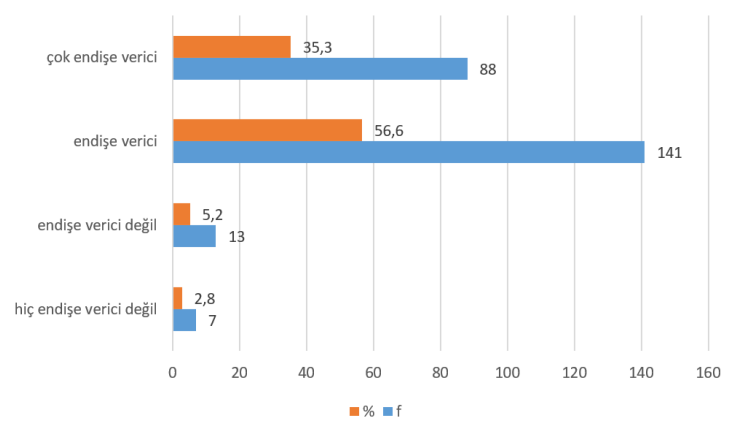

Grafik 4. Küresel iklim değişikliği sorunu hakkında öğrencilerin endişe düzeyleri

Katılımcıların \%56,6'sı küresel iklim değişikliği sorununu endişe verici, \%35,3'ü çok endişe verici bulduklarını ifade etmiștir. Endișe verici bulmayanların oranı \%5,2 ve hiç edișe verici bulmayanların oranı sadece \%2,8'dir. Küresel iklim değişikliği konusunda katılımcıların gelecekle ilgili endişe düzeylerinin yüksek olduğu belirlenmiştir.

Öğrencilerin günlük yaşamda sıklıkla karşılaşabilecekleri bazı uygulamaların küresel iklim değişikliğine olan etkisi hakkındaki görüşleri aşağıda Tablo 4'de sunulmuştur.

Öğrencilere göre, küresel iklim değişikliği üzerine etkili/çok etkili olduğu düşünülen bazı uygulamalar şöyledir; çöp üretimini azaltmak \%86,7, elektrikli aletleri kullanılmadığı zamanlarda fişini çekmek $\% 79,9$, enerji tasarrufu ampul kullanmak \%82,7, evlerde sıcaklığı fazla arttırmak \%64,6, düşük enerji harcayan beyaz eşyalar kullanmak $\% 77,9$, yeniden şarj edilebilir pilleri tercih etmek $\% 85,6$, atıkları türlerine göre ayırmak $\% 90$, evlere yalıtım yaptırmak ve çift camlı pencere kullanmak $\% 71,1$, meyve ve sebzeleri mevsiminde tüketmek $\% 56,2$, alışverişte plastik poşet yerine bez torba veya fileleri tercih etmek $\% 86,3$, kısa mesafelerde yürümeyi veya bisiklet kullanmayı tercih etmek $\% 77,1$, daha az yakıt tüketen araçlar kullanmak \%91,1, geri dönüşümlü ürünler kullanmak \%92,4, toplu taşıma 
araçlarını daha fazla kullanmak \%70,3 ve çamaşır veya bulaşık makinasını tam dolduğunda çalıştırmak \%65,5 olarak tespit edilmiştir. Genel olarak katıımcılar atıklar, geri dönüşüm, çöplerin azaltılması gibi uygulamaların küresel iklim değişikliğinin etkilerinin azaltılmasında etkili olduğunu düşünürken, enerji, yakıt tüketimi, bisiklet veya toplu taşıma araçlarının kullanımı gibi uygulamaların daha az etkili olduğunu düşünmektedirler.

Tablo 4. Öğrenci Görüşlerine Göre Çeşitli Uygulamaların Iklim Değişikliği Üzerine Etkisi

\begin{tabular}{|c|c|c|c|c|c|c|c|c|}
\hline & \multicolumn{2}{|c|}{$\begin{array}{l}\text { Hiç etkili } \\
\text { değil }\end{array}$} & \multicolumn{2}{|c|}{ Etkili değil } & \multicolumn{2}{|c|}{ Etkili } & \multicolumn{2}{|c|}{ Çok etkili } \\
\hline & $f$ & $\%$ & $f$ & $\%$ & $f$ & $\%$ & $f$ & $\%$ \\
\hline Çöp üretimini azaltmak & 9 & 3,6 & 24 & 9,6 & 144 & 57,8 & 72 & 28,9 \\
\hline $\begin{array}{l}\text { Elektrikli aletler kullanmadığı } \\
\text { zaman fişini çekmek }\end{array}$ & 11 & 4,4 & 39 & 15,7 & 134 & 53,8 & 65 & 26,1 \\
\hline Enerji tasarruflu ampul kullanmak & 6 & 2,4 & 37 & 14,9 & 118 & 47,4 & 88 & 35,3 \\
\hline Evlerde sıcaklığı fazla arttırmamak & 23 & 9,2 & 65 & 26,1 & 131 & 52,6 & 30 & 12 \\
\hline $\begin{array}{c}\text { Düşük enerji harcayan beyaz } \\
\text { eşyalar kullanmak }\end{array}$ & 15 & 6 & 40 & 16,1 & 130 & 52,2 & 64 & 25,7 \\
\hline $\begin{array}{l}\text { Yeniden şarj edilebilir pilleri tercih } \\
\text { etmek }\end{array}$ & 10 & 4 & 26 & 10,4 & 117 & 47 & 96 & 38,6 \\
\hline Atıkları türlerine göre ayırmak & 3 & 1,2 & 22 & 8,8 & 103 & 41,4 & 121 & 48,6 \\
\hline $\begin{array}{l}\text { Evlere Isı yalıtımı yaptırmak ve çift } \\
\text { camlı pencere kullanmak }\end{array}$ & 15 & 6 & 57 & 22,9 & 109 & 43,8 & 68 & 27,3 \\
\hline $\begin{array}{l}\text { Meyve ve sebzeleri mevsiminde } \\
\text { tüketmek }\end{array}$ & 32 & 12,9 & 77 & 30,9 & 81 & 32,5 & 59 & 23,7 \\
\hline $\begin{array}{l}\text { Alışverişte plastik poşet yerine bez } \\
\text { torba veya file tercih etmek }\end{array}$ & 10 & 4 & 24 & 9,6 & 129 & 51,8 & 86 & 34,5 \\
\hline $\begin{array}{c}\text { Kısa mesafelerde yürümeyi veya } \\
\text { bisikleti tercih etmek }\end{array}$ & 27 & 10,8 & 30 & 12 & 93 & 37,3 & 99 & 39,8 \\
\hline $\begin{array}{c}\text { Daha az yakıt tüketen araçlar } \\
\text { kullanmak }\end{array}$ & 4 & 1,6 & 18 & 7,2 & 90 & 36,1 & 137 & 55 \\
\hline Geri dönüşümlü ürünler kullanmak & 6 & 2,4 & 13 & 5,2 & 106 & 42,6 & 124 & 49,8 \\
\hline $\begin{array}{l}\text { Toplu taşıma araçlarını daha fazla } \\
\text { kullanmak }\end{array}$ & 32 & 12,9 & 42 & 16,9 & 98 & 39,4 & 77 & 30,9 \\
\hline $\begin{array}{l}\text { Çamaşır veya bulaşık makinasını } \\
\text { tam dolduğunda çalıştırmak }\end{array}$ & 30 & 12 & 56 & 22,5 & 106 & 42,6 & 57 & 22,9 \\
\hline
\end{tabular}

Küresel iklim değişikliği ile mücadele ve halkın adaptasyonuna ilişkin kamu kurum/kuruluşlarının yürüttüğü çalışmalar hakkında öğrencilerin farkındalıkları aşağıda Grafik 5'de sunulmuştur.

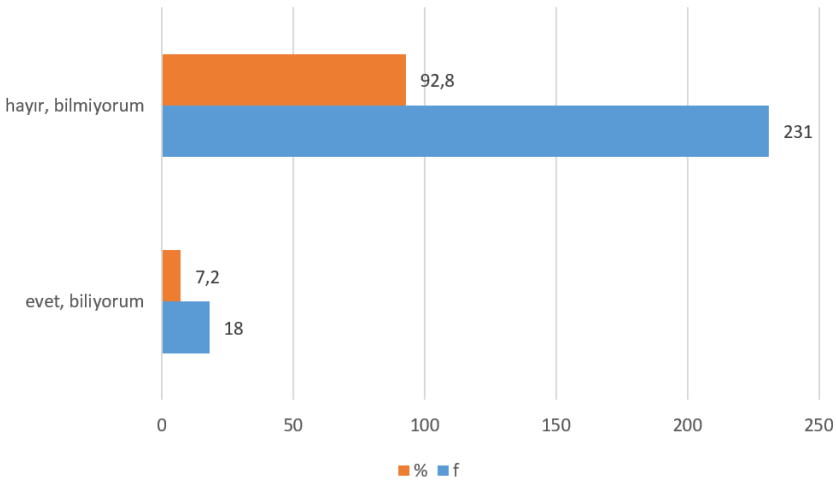

Grafik 5. Küresel iklim değişikliği ile ilgili mücadele ve halkın adaptasyonuna ilişkin yürütülen çalışmalardan öğrencilerin haberdar olup/olmamaları

Küresel iklim değişikliği ile ilgili mücadele ve halkın adaptasyona ilişkin yürütülen çalışmalar hakkında öğrencilerin \%92,8'inin çalışmalardan haberdar olmadıkları belirlenmiştir. Küresel iklim değişikliği ile ilgili mücadele ve halkın adaptasyonu hakkında kamu kurum ve kuruluşları tarafından yürütülen çalışmalar hakkında bilgi sahibi olduğunu ifade eden öğrencilerin görüşleri aşağıda sunulmuştur. 
- Belediyelerin bu olaylardan etkilenen insanlar için barınak, yiyecek vb. sağlaması.

- Etraftaki çöp kutularının çoğaltııması.

- NatGeo gibi TV kanallarında iklim değişikliği ile ilgili belgeseller yayınlanması.

- Bazı marketlerde poşetlerin ücretli verilmesi.

- Belediyeler arabalar yerine toplu taşıma araçları kullanın diyor.

- Yağlar toplanıyor, geri dönüşüm yapılıyor.

- Bazı bölgelerde ağaçlandırma çalışması yapııması.

- Çöplerin türlerine göre toplanması ve türlerine göre belediyelerin çöp kutuları yerleştirmesi.

- Enerji kaynaklarının daha az kullanılmasına yönelik bilgilendirme çalışmaları.

- Güneş panellerinin üretilmesi.

- Kamu spotlarının yayınlanması.

\section{Sonuç ve Tartışma}

Küresel iklim değişikliğinin nedenleri ve sonuçları hakkında lise düzeyinde yapılan çalışmalar incelendiğinde öğrencilerin genel olarak sınırlı bilgilere sahip oldukları belirlenmiştir (Ayvacı ve Çoruhlu, 2009; Kılınç ve diğ, 2008; Pekel ve diğ., 2007; Shealy ve diğ., 2017). Bu çalışmada elde edilen bulgular ile literatürdeki ilgili araştırmaların bulguları birbirini destekler niteliktedir. Katıımcıların iklim değişikliği konusunda bilgi düzeylerinin düşük olmasının pek çok sebebi olabilir. Topçu ve Atabey (2016) ve Alp, Ertepinar, Tekkaya, ve Yilmaz (2006) ders programlarında çevre eğitimine yönelik hedef ve kazanımların yetersiz olduğunu ve resmi fen müfredatının uygulanmasında çevre konularının yeterince vurgulanmadığını belirtmektedir. Fen bilgisi, sınıf, biyoloji öğretmen adayları ve ilkokul öğretmenleri ile yapılan araştırmalarda, katıımcıların iklim değişikliği konusunda sınırlı bilgilere ve kavram yanılgılarına sahip oldukları ifade edilmektedir (Arsal, 2010; Benzer ve Şahin, 2013; Bozkurt ve Kaya, 2008; Şenel ve Güngör, 2009; Temelli, Kurt ve Keçci-Kurt, 2011). Öğretmen adaylarının iklim değişikliği ile ilgili kavram yanılgılarının devam etmesi yükseköğretim kurumlarında da etkili bir çevre eğitimi verilemediği şeklinde yorumlanabilir. Özellikle öğretmen adaylarının sahip oldukları kavram yanılgılarının düzeltilememesi ve küresel ısınma konusunda bilgi düzeylerinin düşük olması, doğal olarak öğrencilerin bilgi düzeylerini de olumsuz yönde etkileyecektir. Ancak Aydın (2014) lise öğrencilerinin küresel ısınma konusundaki bilgi düzeylerini belirlemeye çalıştığı araştırmasında elde ettiği sonuçlar gerek yüzde olarak oldukça yüksek gerekse ifadeler bakımından oldukça bilimsel ve yeterli görülmektedir. Bu çalışmaya göre küresel ısınmanın sonuçları konusunda lise öğrencilerinin genellikle bilgi sahibi oldukları görülmektedir. Aydın (2014), çalışmasında Yalçın (2010) tarafından geliştirilen küresel ısınma bilgi anketi kullanmıştır. Ankette öğrencilerden küresel ısınma ile ilgili hazırlanmış 20 adet hazır ifadelere katılma düzeylerini (5'li Likert) ifade etmeleri istenmiştir. Benzer şekilde İncekara ve Tuna (2010), çalışmasında çevre sorunları hakkında seçeneklerin yer aldığı (hiç duymadım, duydum fakat açıklayamam, açıklayacak kadar bilgim var, tam olarak biliyorum) ölçme aracı ile lise öğrencilerinin küresel ısınmayı açıklayabilecek kadar bilgisi olduğunu tespit etmiştir. Öğrenciler soruları yanıtlarken doğrudan kendi cümleleri ile tanımlama yapmadıkları ve kendi düşüncelerini yazarak ifade etmedikleri için küresel ısınma konusunda bilgi düzeyleri yüksek çıkmış olabilir.

Katılımcıların yarıya yakını küresel iklim değişikliğini tanımlayamazken geriye kalan kısmının tanımlarının da yüzeysel ve bilimsellikten uzak olduğu, kavram yanılgıları ve yanlış bilgilere sahip oldukları belirlenmiştir. Çok küçük bir öğrenci grubunun küresel iklim değişikliğini tanımlamada "sera etkisi yaratan gazlardan" bahsetmesi oldukça önemli ve düşündürücüdür. Araştırma verilerine göre öğrencilerin kavram yanılgılarına sahip oldukları görülmektedir. Benzer şekilde Ayvacı ve Çoruhlu (2009), Bozkurt ve Kaya (2008) ve Pekel ve diğ., (2007) çalışmalarında öğrencilerin küresel ısınma ile ozon tabakasının incelmesi veya delinmesi arasında ilişki kurduğunu tespit etmiştir. En sık karşılaşılan kavram yanılgısı her kademedeki ve yaştaki bireylerde gözlenen küresel ısınma ile ozon tabakası arasında doğrudan ilişki bulunduğunun zannedilmesidir (Ayvacı ve Çoruhlu, 2009; Pekel ve diğ., 2007). Aslında sera gazları küresel ısınma üzerinde etkili olurken, ozon tabakasının küresel ısınma üzerinde doğrudan etkisi olmamaktadır. Araştırmalarda en sık karşılaşılan kavram yanılgılarından biri ozon tabakasının incelmesi sonucu küresel ısınmanın artacağını düşünmesi, sera etkisinin dünyayı güneşin uv ışınlarından koruduğu ve küresel ısınma sonucu sıcaklık artışının cilt kanserine neden olacağının sanılmasıdır (Benzer ve Şahin, 2013; Bozdoğan, 2009; Bozkurt ve diğ., 2005; Bozkurt ve Aydoğdu, 2004; Darçın ve diğ., 2006; Hansen, 2009; Keinonen ve diğ., 2016; Kılınç ve diğ., 2008; Matkins ve Bell, 2007; Michail, Stamou ve Stamou, 2007; Papadimitrio, 2004; Pekel, 2005;). Öğrencilerin kavram yanılgılarının sebeplerinden biri öğretmenlerin küresel iklim değişikliği hakkında doğru ve yeterli bilgi sahibi olmamasından kaynaklanıyor olabilir. Nitekim literatürde öğretmen adaylarının çevre hakkında bilgi seviyelerinin yetersiz olduğunu ve iklim değişikliğinin önlenmesi için alınması gereken tedbirlerin farkında olmadıklarını ve bazı kavram yanılgılarına sahip olduklarını gösteren araştırmalar bulunmaktadır (Benzer ve Şahin, 2013; Demirkaya, 2008; Michail, ve diğ., 2007; Öztaş ve Kalıpçı, 
2009; Papadimitriou, 2004). Öncelikle öğretmen adaylarının ve öğretmenlerin kavram yanılgıları ve yanlış bilgileri düzeltilmezse iklim değişikliği öğrencilere eksik ve yanlış öğretilmeye devam edecektir. Öğrencilerin kavram yanılgılarının sebepleri arasında informal eğitimin önemli kaynağı olan medyadan kaynaklanabileceği de ifade edilmektedir (Hansen, 2009). Araştırmalarda öğretmen ve öğrencilerin çevre sorunlarıyla ilgili bilgi kaynaklarının başta televizyon olmak üzere daha çok yazılı ve görsel medya olduğu ifade edilmektedir (Bozdoğan, 2011; Bozkurt ve Kaya, 2008; Ergin ve diğ., 2017; Kılınç ve diğ., 2008; Öztaş ve Kalıpçı, 2009; Taştepe ve Aral, 2014; Vaizoğlu, ve diğ., 2005).

Katılımcılara göre, küresel iklim değişikliğinin en önemli sebepleri, çevre kirliliği ve insanların bilinçsiz davranışlarıdır. Diğer ifadeler de incelendiğinde, öğrenciler küresel iklim değişikliğinin temelinin ve çevre sorunlarının insan kaynaklı olduğunun farkındadır. Benzer şekilde Aydın'ın (2014) çalışmasına katılan lise öğrencileri, küresel ısınmada hızlı sanayileşmenin rolü olduğunu ifade etmişlerdir. Tetik ve Acun'un (2015) araştırmasında ise yükseköğretim öğrencileri, küresel ısınma ve iklim değişikliğinde hava kirliliği, fosil yakıt tüketimindeki artış ve ormanların yok edilmesinin en çok; sera gazlarının salınımındaki artışın orta düzeyde ve göçler ile çarpık kentleşmenin az etkili olduğunu ifade etmişlerdir. Ancak küresel iklim değişikliğinin tanımlanmasında olduğu gibi sebeplerinin açıklanmasında da ozon tabakasının delinmesi, dünyanın hareketi, zararlı güneş ışınları ve coğrafi konum ifadeleri öğrencilerin kavram yanılgıları ve eksik bilgilerinin olduğunu göstermektedir. Arsal (2010), çalışmasında sınıf ve fen bilgisi öğretmen adaylarının sera etkisinin nedenleri ile ilgili kavram yanılgılarını; dünyaya daha fazla güneş ışınlarının gelmesi, asit yağmurlarının olması, tarımda daha fazla hormon kullanılması olarak tespit etmiştir. Bahar ve Aydın (2002) da sınıf öğretmeni adaylarının sera etkisini asit yağmurları ile ilişkilendirdiklerini ve bu konuda kavram yanılgısına sahip olduklarını ifade etmektedir. Katılımcıların küresel iklim değişikliğinin etkileri hakkında yeterli bilgiye sahip olmadıkları belirlenmiştir. Genel olarak iklim değişikliğinin etkileri fiziksel değişimler, canlılar üzerine olan etkiler ve ekonomik etkiler olarak gruplandırılabilir. Mevsimlerin aşııı sıcak veya aşırı soğuk olması, buzulların erimesi, havaların ısınması, kuraklık, deniz seviyesinin yükselmesi, doğa olaylarının artması gibi ifadeler fiziksel değişimlere, hayvanların neslinin tükenmesi, doğanın (tüm canlılar) olumsuz etkilenmesi, hastalıklara yol açması, insan yaşam kalitesini düşürmesi, hayvanların göç etmesi, besin zincirinin bozulması, ormanların ve çevrenin yok olması, canlıların genlerinin değişmesi ifadeleri iklim değişikliğinin canlılar üzerine olan etkilerine ve ekonomik faaliyetlerin olumsuz etkilenmesi, tarım ürünlerinin veriminin azalması ifadeleri iklim değişikliğinin ekonomiye olan olumsuz etkilerine örnek verilebilir. Küresel iklim değişikliğinin etkileri hakkındaki ifadelerde (diğer ifadelere oranla) mevsimsel değişimler ve buzulların erimesinin daha sıklıkla tekrarlandığı belirlenmiştir. Benzer şekilde literatürdeki araşıırmalar incelendiğinde, katılımcılara göre iklim değişikliğinin sonuçları; buzulların erimesi, mevsimsel değişiklikler, kuraklık ve çölleşmenin artması, susuzluk, canlıların yok olması, şiddetli yağışların artması, sellerin oluşması, deniz seviyesinin yükselmesi, yeni hastalıkların ortaya çıkması olarak tespit edilmiştir (Arsal, 2010; Aydın, 2014; Ayvacı ve Çoruhlu, 2009; Bozdoğan ve Yanar, 2010; Harshal ve Atul, 2011; Tetik ve Acun, 2015; Yalçın, 2010).

Katılımcıların çok büyük bir kısmı (\%91.9) küresel iklim değişikliğinin neden olabileceği olumsuzluklardan endişe duymaktadır. Endişe sebepleri, küresel iklim değişikliği konusunda yeterli ve doğru bilgiye sahip olmamanın yanında iklim değişikliğinin olası sonuçları ile mücadele etme, etkilerini azaltma konusunda da yeterli bilgiye sahip olamamalarından kaynaklanıyor olabilir. TV, internet gibi yazılı ve görsel medyada iklim değişikliğinin sonuçları hakkında yayınlanan belgesel, haberler vb. yayınlarda sorunun önemi vurgulanırken, iklim değişikliği ile nasıl mücadele edilebileceği, olası etkilerinin azaltılabileceği yani çözüm yollarının olduğu ve gerekli önlemler çok geç olmadan alınabilirse felaket senaryolarının yaşanmayacağı vurgusuna yeterince yer verilmemesi de öğrencilerin kaygı düzeylerinin yüksek olmasında bir etken olabilir. Ayrıca öğrenciler her geçen gün artan çevre sorunlarına ve felaketlerine şahit olmaktadır. Günümüzde artan teknoloji ve iletişim ağı dünyanın herhangi bir bölgesinde yaşanan felaketleri gözler önüne sermektedir. İzledikleri veya okudukları çevre sorunları haberleri de kaygı düzeylerinin yükselmesine neden olabilir. Muhtemelen derslerinde anlatılan konularda da çevre ile ilgili olumsuz örneklerde endişe düzeylerinin yükselmesine neden olmaktadır. Ancak öğrencilerin kaygı düzeylerinin yüksek olması çevre sorunlarını ve ileride olabilecek felaketleri önemsedikleri şeklinde yorumlanabilir. Bu durum oldukça önemli olup bir fırsata dönüştürülmelidir. Öğrencilere, gerekli tedbirler alınmazsa, birey olarak üzerimize düşen görev ve sorumluluklar yerine getirilmezse daha büyük felaketlerin yaşanabileceği öğretilmelidir. İklim değişikliğinin etkilerini ortadan kaldırmanın mümkün olduğu, toplumun tüm kesimlerinin iş birliği ile bu sorunun etkilerinin en aza indirilebileceği umudu da mutlaka verilmelidir. Dünya üzerinde geri dönüşüm, temiz enerji kaynakları, sağılklı ve temiz ulaşım alternatifleri, doğal kaynakların verimli kullanımına ilişkin güzel örnekler verilerek öğrencilerde farkındalık arttırılabilir.

Öğrenciler, genel olarak atıklar ile ilgili uygulamaların (atıkları türlerine göre ayırma, geri dönüşümlü ürünler kullanma gibi) enerji ile ilgili uygulamalara (toplu taşıma araçlarını kullanma, ısı yalıımı, 
evlerde sıcaklığın fazla arttırılması vb.) oranla küresel iklim değişikliğinin etkilerini arttırmada daha fazla etkili olduğunu düşünmektedir. Öğrencilerin geri dönüşüm faaliyetlerine katılmak, evlerde atıkları ayırmak, alışverişlerde plastik poşet yerine file vb. kullanmak gibi faaliyetlere sıcak baktıkları düşünülebilir. Bu durumdan yararlanılarak geri dönüşümün yaygınlaştırılması için tüm kamu kurum ve kuruluşları, sivil toplum örgütleri, belediyeler iş birliği yaparak, gerekli düzenleme ve yasalar çıkarılarak etkili faaliyetler düzenlemelidir. Ancak katılımcıların bir kısmı toplu taşıma araçlarını kullanmama, sebze ve meyveleri mevsiminde tüketmeme, çamaşır ve bulaşık makinalarını tam dolmadan kullanmanın enerji tüketimini arttırdığını, artan enerji ihtiyacını karşılamak için üretimin artması gerektiğini ve buna bağlı olarak sera etkisi gazların artarak küresel ısınmaya neden olacağı konusunda ilişki kurmakta zorlandıkları söylenebilir. Öğretim programlarında ve çevre ile ilgili derslerde özellikle enerji ihtiyacının artmasına bağlı olarak enerji üretiminin artması sonucunda sera gazlarının artacağı vurgulanmalıdır. Ancak yukarıda da ifade edildiği gibi hem öğrencilerin kaygı düzeylerini düşürmek hem de bu problemin bir çözümünün olduğunu anlatabilmek için yenilenebilir ve çevre dostu enerji kaynaklarının küresel ısınmanın azaltılmasında oldukça etkili olduğu belirtilmelidir.

Küresel iklim değişikliği ile mücadele ve halkın adaptasyonu konusunda katıımcıların büyük bir çoğunluğunun yürütülen çalışmalar hakkında bilgi sahibi olmadıkları tespit edilmiştir. Bu durum, iklim değişikliği ile ilgili mücadele ve halkın adaptasyonu ile ilgili yürütülen çalışmaların az olmasından veya görünür olmamasından kaynaklanıyor olabilir. Tetik ve Acun (2015) araştırmasında öğrenciler küresel iklim değişikliği ile mücadelede bireysel çabalardan çok devletin önlem almasının daha etkili olacağını ifade etmişlerdir. İklim değişikliği ile mücadele de kamu kurum ve kuruluşlarının yürüttüğü faaliyetlerin sayısının, görünürlüğünün ve katılımın arttıııması oldukça önemlidir. Faaliyetlerin görünürlüğü ve katılımın artırımasında özellikle yazılı ve görsel medyaya önemli görevler düşmektedir. Örneğin; Kılınç ve diğerleri (2008) çalışmasında lise öğrencilerinin \%60'nın, Güley (2009) çalışmasında ise üniversite öğrencilerinin \%81'nin basın-yayın-medya yoluyla küresel ısınma terimini ilk kez öğrendikleri sonucuna ulaşmışlardır. Sonuç olarak küresel ısınma ile mücadele ve halkın adaptasyonu konusunda yazılı ve görsel medyadan daha fazla yararlanılmalıdır.

Küresel iklim değişikliği hakkında bireylerin farkındalık ve bilgi düzeylerinin arttırımasında eğitim en önemli role sahiptir. Bireylerin çevre problemleri hakkında farkındalıkları attırılacak olursa bu sorunlara bir çözüm bulunabilir (Aksüt, Doğan ve Bahar, 2016). Ayrıca bireylerin kaygı düzeylerini düşürmek geleceğe daha umutla bakmalarını sağlayacaktır. Önemli çevre sorunlarından biri olan küresel iklim değişikliği üzerinde durulması, halka anlatılması, küçük yaşlardan itibaren bu konu hakkında bireylerin bilgilendirilmesi, farklı ortamlarda konuşulması ve hepsinden önemlisi halkın tüm kesimlerinde farkındalık yaratılması gereken bir konudur. İklim değişikliğinin etkilerini halkın tüm kesimlerine anlatılmadan çözülemeyeceği unutulmamalıdır. Bu anlamda en büyük görev eğitimcilere ve bu konuda politikalar üretecek, yasalar çıkaracak siyasi otoritelere düşmektedir. İklim değişikliğine gençlerin gözünden bakarak, onların algılarını, bilgi düzeylerini, tutumlarını anlamaya çalışmak iklim değişikliği ile mücadele konusunda politika geliştirmek için önemlidir.

Çalışmadan elde edilen bulgulara göre geliştirilen öneriler aşağıda sunulmuştur:

1. Öğrencilerin iklim değişikliği ile ilgili kavram yanılgıları, yanlış ve eksik bilgileri giderilmeli, özellikle iklim değişikliği ile ozon tabakası arasındaki kavram yanılgısının sebepleri sorgulanmalıdır.

2. Öğrencilerin iklim değişikliğinin en önemli sebebinin insan olduğunun farkında olmaları fırsata dönüştürülmeli ve bireysel olarak iklim değişikliği ile nasıl mücadele edilebileceği, birey olarak üzerine düşen görev ve sorumluluklar öğretilmelidir.

3. Öğrencilerin endişe düzeylerinin düşürülmesinde iklim değişikliği ile mücadele edilebileceği vurgulanmalı, bu konuda medyanın gücünden yararlanılmalıdır.

4. Öğrencilerin geri dönüşüm uygulamalarına katıma istekleri değerlendirilerek, ülke genelinde geri dönüşüm uygulamaları arttırılmalıdır. Ayrıca öğretim programlarında ve çevre ile ilgili ders içeriklerinde enerji konusu ve yenilenebilir enerji kaynaklarına daha fazla yer verilerek önemi vurgulanmalıdır.

5. İklim değişikliği ile mücadele ve halkın adaptasyonu konusunda kamu kurum ve kuruluşlarının faaliyet sayıları, görünürlüğü ve katıımı arttırılmalı, bu konuda da medyanın gücünden yararlanılmalıdır. 
Akgün, A., Duruk, Ü. ve Tokur, F. (2017). Gözlem gezisi yönteminin öğretmen adaylarının çevreye ve çevre eğitimine ilişkin görüşlerine etkisi. Route Educational and Social Science Journal, 4(2), 65-82. Doi: 10.17121/ressjournal.594

Akgün, I.H. ve Atmaca, Y. (2015). Ortaokul 5, 6 ve 7. sınıf sosyal bilgiler dersinde ekoloji konularına ilişkin kazanımların gerçekleşme düzeyi. Adıyaman Üniversitesi Eğitim Bilimleri Dergisi, 5(2), 168-189. Doi: 10.17984/adyuebd.15602

Aksan, Z. ve Çelikler, D. (2013). İlköğretim öğretmen adaylarının küresel ısınma konusundaki görüşleri. Eskişehir Osmangazi Üniversitesi Sosyal Bilimler Dergisi, 14(1), 49-67.

Aksu, M., Temeloğlu, E., Özkaya E. ve Gündeğer, M. (2012). Lise düzeyinde turizm eğitimi alan öğrencilerin turizm ve çevre bilinci üzerine bir araştırma. Düzce Üniversitesi Sosyal Bilimler Enstitüsü Dergisi, 2(2), 42-61.

Aksüt, P., Doğan, N. ve Bahar, M. (2016). If you change yourself, the world changes: the effect of the exhibition on preservice science teachers' views about global climate change. Eurassia Journal of Mathematics, Science and Technology Education, 12(12), 2933-2947.

Alp, E., Ertepinar, H., Tekkaya, C. ve Yilmaz, A. (2006). A statistical analysis of children's environmental knowledge and attitudes in Turkey. International Research in Geographical and Environmental Education, 15(3), 210-223.

Arsal, Z. (2010). İlköğretim öğretmen adaylarının sera etkisi ile ilgili kavram yanılgıları. İlköğretim Online, 14(1), 229-240.

Aydın, F. (2014). Ortaöğretim öğrencilerinin küresel ısınma konusundaki bilgi düzeylerinin belirlenmesi. Turkish Journal of Education, 3(4), 15-27. Doi: 10.19128/turje.7299116

Ayvacı, H. Ş. ve Çoruhlu, T. Ş. (2009). Öğrencilerin küresel çevre sorunlarına bakışları ve kavram yanılgılarının belirlenmesine yönelik gelişimsel bir araştırma. Hasan Ali Yücel Eğitim Fakültesi Dergisi, 12(2), 11-25.

Bahar, M. (2003). Misconceptions in biology education and conceptual change strategies. Kuram ve Uygulamada Eğitim Bilimleri, 3(1), 55-64.

Bahar, M. ve Aydın, F. (2002). Sını öğretmenliği öğrencilerinin sera gazları ve global ısınma ile ilgili anlama düzeyleri ve hatalı kavramları. V. Ulusal Fen Bilimleri ve Matematik Eğitimi Kongresi, Ankara.

Bal, Ş. (2004). Fen bilgisi öğretmen adaylarının sera etkisi ile ilgili kavram yanılgılarının tespiti. Eğitim Araştırmaları Dergisi, 17, 102-111.

Benzer, E. ve Şahin, F. (2013). Proje tabanlı öğrenme yaklaşımının lisans öğrencilerinin çevreye yönelik problem çözme becerilerine etkisi. Illköğretim Online, 12(2), 383-400. 
June 2019, Volume 3, Is sue 1,84-100

Bozdoğan, A. E. (2009). An investigation on Turkish prospective primary school teachers' perceptions about global warming. World Applied Sciences Journal, 7(1), 43-48.

Bozdoğan, A. E. (2011). Küresel ısınma sorunu hakkında eğitim alanında yapılan çalışmalardan bir derleme. Kuram ve Uygulamada Eğitim Bilimleri, 11(3), 1609-1624.

Bozdoğan, A. E. ve Yanar, O. (2010). Sınıf öğretmeni adaylarının küresel ısınmanın gelecek yüzyıldaki etkilerine ilişkin görüşleri. Karadeniz Fen Bilimleri Dergisi, 1(2), 48-60.

Bozkurt, O. ve Aydoğdu, M. (2004). İlköğretim 6. 7. ve 8. sınıf öğrencilerinin "ozon tabakası ve görevleri” hakkındaki kavram yanılgıları ve oluşturma şekilleri. Kastamonu Eğitim Dergisi, 12(2), 369-376.

Bozkurt, O. ve Kaya, O. N. (2008). Teaching about ozone layer depletion in Turkey: Pedagogical content knowledge of science teachers. Public Understanding of Science, 17, 261- 276.

Bozkurt, O., Aydın, H., Yaman, S., Uşak, M., \& Gezer, K. (2005). Sixth, seventh and eighth-year students' knowledge levels about greenhouse effect, ozone layer and acid rain. Mediterranean Journal of Educational Studies, 10(2), 81-95.

Darçın, E. S., Bozkurt, O., Hamalosmanoğlu, M., \& Köse, S. (2006). Determination of elementary students' level of knowledge and misconceptions about greenhouse effect. International Journal of Environmental and Science Education, 1(2), 104-115.

Demircan, M., Turan, N., Arabacı, H., Coşkun, M., Türkoğlu, N. ve Çiçek, İ. (2016). Gündem belirleme modeline göre yazılı basındaki iklim değişikliği haber ve köşe yazılarının analizi. TÜCAUM Uluslararası Coğrafya Sempozyumu, 13-14 Ekim 2016, Ankara.

Demirkaya, H. (2008). The understandings of global warming and learning styles: A phenomenographic analysis of prospective primary school teachers. Educational Sciences: Theory ve Practice, 8(1), 51-58.

Derman, M., Çakmak, M., Yaşar, M. D. ve Gürbüz, H. (2013). Sera etkisinin iklim değişikliği üzerindeki etkisi: Öğretmen adaylarının görüşlerine göre. Uluslararası Hakemli Beşeri ve Akademik Bilimler Dergisi, 2(3), 12-25.

Ergin, A., Akbay, B., Özdemir, C. ve Uzun, U. S. (2017). Tıp fakültesi öğrencilerinin küresel ısınma ve sağlığa etkileri ile ilgili bilgi, tutum ve davranışları. Pamukkale Tıp Dergisi, 2, 172-180.

Fraenkel, J. R., \& Wallen, N. E. (2009). How to design and evaluate research in education. San Francisco: McGraw-Hill.

Güley, A. Ö. (2009). Bolu Abant lizzet Baysal üniversitesi öğrencilerinin küresel ısınma hakkındaki bilgi düzeylerinin ölçülmesi (Yayımlanmamış yüksek lisans tezi). Erciyes Üniversitesi, Sağlık Bilimleri Enstitüsü, Kayseri.

Hansen, P. J. K. (2009). Knowledge about the greenhouse effect and the effects of the ozone layer among Norwegian pupils finishing compulsory education in 1989, 1993, and 2005- What now? International Journal of Science Education, 1-23. Doi: 10.1080/09500690802600787

Harshal, T. P., \& Atul, R. (2011). Assessment of awareness regarding climate change and its health hazards among the medical students. Indian J. Occup Environ Medicine, 15, 42-45. Doi: $10.4103 / 0019-5278.82999$ 
İncekara, S. ve Tuna, F. (2010). Ortaöğretim öğrencilerinin çevresel konularla ilgili bilgi düzeylerinin ölçülmesi: Çankııı lli örneği. Marmara Coğrafya Dergisi, 22, 168-182.

Kahraman, S., Yalçın, M., Özkan, E. ve Ağgül, F. (2008). Sınıf öğretmenliği öğrencilerinin küresel ısınma konusundaki farkındalıkları ve bilgi düzeyleri. Gazi Eğitim Fakültesi Dergisi, 28(3), 249263.

Karasar, N. (2012). Bilimsel araştırma yöntemi: Kavramlar, ilkeler, teknikler. Ankara: Nobel.

Keinonen, T., Palmberg, I., Kukkonen, J., Panula, E. Y., \& Vilkonis, R. (2016). Higher education students' perceptions of environmental issues and media coverage. Discourse and Communication for Sustainable Education, 7(1), 5-22.

Khalid, T. (2003). Pre-service high school teachers' perceptions of three environmental phenomena. Environmental Education Research, 9(1), 35-50.

KIlınç, A., Stanisstreet, M., \& Boyes, E. (2008). Turkish students' ideas about global warming. International Journal of Environmental \& Science Education, 3(2), 89-98.

Kışoğlu, M., Yıldırım, T., Salman, M. ve Sülün, A. (2016). İlkokul ve ortaokullarda çevre eğitimi verecek öğretmen adaylarında çevre sorunlarına yönelik davranışların araştıııması. Erzincan Üniversitesi Eğitim Fakültesi Dergisi, 18, 299-318.

Matkins, J. J., \& Bell, R. L. (2007). Awakening the scientist inside: Global climate change and the nature of science in an elementary science methods course. Journal of Science Teacher Education, 18, 137-163.

Michail, S., Stamou, A. G., \& Stamou, G. P. (2007). Greek primary school teachers' understanding of current environmental issues: An exploration of their environmental knowledge and images of nature. Science Education, 91, 244-259.

Oğuz, D., Çakıcı, I. ve Kavas, S. (2011). Yükseköğretimde öğrencilerin çevre bilinci. Süleyman Demirel Üniversitesi Orman Fakültesi Dergisi, 12, 34-39.

Oluk, A. E., \& Oluk, S. (2007). Yükseköğretim öğrencilerinin sera etkisi, küresel ısınma ve iklim değişikliği algılarının analizi. Dokuz Eylül Üniversitesi Buca Eğitim Fakültesi Dergisi, 22, 45-53.

Özdemir, O. (2010). Doğa deneyimine dayalı çevre eğitiminin ilköğretim öğrencilerinin çevrelerine yönelik algı ve davranışlarına etkisi. Pamukkale Üniversitesi Eğitim Fakültesi Dergisi, 27, 125138.

Öztaş, F., \& Kalıpçı, E. (2009). Teacher candidates' perception level of environmental pollutant and their risk factors. International Journal of Environmental and Science Education, 4(2), 185-195.

Papadimitriou, V. (2004). Prospective primary teachers' understanding of climate change, greenhouse effect and ozone layer depletion. Journal of Science Education and Technology, 13(2), 299-307.

Pekel, F. O. (2005). High school students' and trainee science teachers' perceptions of ozone layer depletion. Journal of Baltic Science Education, 1(7), 12-21.

Pekel, F. O., Kaya, E. ve Demir, Y. (2007). Farklı lise öğrencilerinin ozon tabakasına ilişkin düşüncelerinin karşılaştııılması. Kastamonu Eğitim Dergisi, 15(1), 169-174. 
Shealy, R., Klotz, L., Godwin, A., Hazari, Z., Potvin, G., Barclay, N., \& Cribbs, J. (2017). High school experiences and climate change beliefs of first year college students in the United States. Environmental Education Research.

Swim, J. K., Clayton, S., \& Howard, G. S. (2011). Human behavioral contributions to climate change psychological and contextual drivers. American Psychologist, 66(4), 251-264.

Şenel, H. ve Güngör, B. (2009). Üniversite öğrencilerinin küresel ısınma hakkındaki bilgilerinin ve kavram yanılgılarının tespiti. E-Journal of New World Sciences Academy, 4(4), 1207-1225.

Taştepe, T. ve Aral, N. (2014). Üniversite öğrencilerinin çevresel bilgi ve tutumlarının incelenmesi. Eğitim ve Öğretim Araştırmaları Dergisi, 3(4), 142-153.

Temelli, A., Kurt, M. ve Keçci-Kurt, S. (2011). Illköğretim öğretmenlerinin küresel ısınmaya ilişkin görüşleri. Kuramsal Eğitimbilim, 4(2), 208-220.

Tetik, N. ve Acun, A. (2015). Turizm öğrencilerinin küresel ısınma ve iklim değişikliği algısı ve görüşleri. Uluslararası Sosyal Araştırmalar Dergisi, 41(8), 1459-1476.

Topçu, M. S. ve Atabey, N. (2016). Alan gezilerinin ortaokul öğrencilerinin çevre konusundaki bilgi ve tutumları üzerine etkisi. YYÜ Eğitim Fakültesi Dergisi, 13(1), 494-513.

Uğulu, I., \& Erkol, S. (2013). Investigation of Biology pre-service teachers' attitudes toward environment in terms of some variables. NWSA-Education Sciences, 8, 79-89.

URL-1: http://kecioren.meb.gov.tr/www/ortaogretim-kurumlarimiz/icerik/398

Ünlü, İ., Sever, R. ve Akpınar, E. (2011). Türkiye'de çevre eğitimi alanında yapılmış küresel ısınma ve sera etkisi konulu akademik araştırmaların sonuçlarının incelenmesi. Erzincan Eğitim Fakültesi Dergisi, 13(1), 39-54.

Vaizoğlu, S., Altıntaş, H., Temel, F., Ahrabi, A. F., Aydoğan, D. ve Bostancı, S. (2005). Bir tıp fakültesi son sınıf öğrencilerinin çevre bilincinin değerlendirilmesi. TSK Koruyucu Hekimlik Bülteni, 4(4), 151-171.

Yalçın, F. (2010). Illköğretim öğrencilerinin küresel ısınma ve sera etkisi konularındaki bilgi düzeylerinin ve yanlış kavramalarının belirlenmesi üzerine bir çalışma (Yayımlanmamış yüksek lisans tezi) Gazi Üniversitesi, Eğitim Bilimleri Enstitüsü, Ankara.

Yıldırım, A., \& Şimşek, H. (2011). Sosyal bilimlerde nitel araştırma yöntemleri. Ankara: Seçkin Yayıncllik. 